\title{
СКВАЖИННАЯ ГРАВИМЕТРИЯ В ПРОМЫСЛОВОЙ ГЕОФИЗИКЕ
}

(ЗАO "Гравиразведка")

Гравиметрический каротаж на сегодняшний день один из наиболее интересных и динамично развиваюшихся методов промысловой и разведочной геофизики. Работы проводимые сегодня показывают высокую эффективность ГрК (Гравиметрического каротажа) при поиске и изучении нефтегазоносньтх залежей, в т.ч. при отбивке газоводяньх контактов, а также при оценке эффективньх мощностей продуктивных коллекторов. В связи с этим, в последнее время, возникла необходимость оценить современное состояние ГрК, показать возможности метода при решении поисковых и оценочных задач, а также указать области наиболее эффективного применения данного метода.

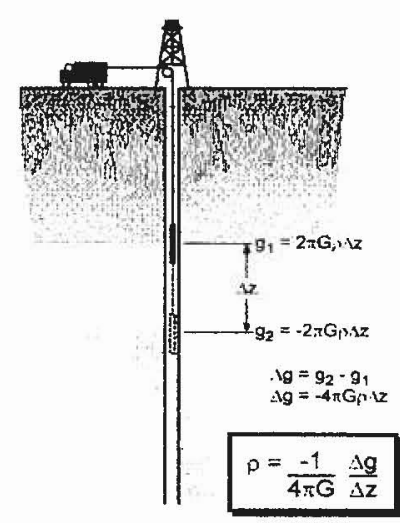

Рис. 1 Расчет плотности бесконечной горизонтальной плиты

Основы метода. Для измерений используется скважинный гравиметр LaCoste\&Romberg, paзpa6oтанный в 2004 году, позволяющий решать задачи, поставленные перед современной скважинной гравиметрией с необходимой точностью.

В основе исследований лежит измерение гравитационных эффектов, создаваемых различными породами в зависимости от их литологинеского состава и типа флюида, содержащегося в поровом пространстве. Суть метода заключается в измерении силы тяжести в пунктах профиля. Вдоль ствола скважины для расчета плотности между пунктами профиля в основу берется грирапение силы тяжести, g, создаваемое бесконечной горизонтальной плитой, состоящей из горной породы равномерной плотности (рис.1).

По прирапениям силы тяжести между пунктами с известными превыпеннями можно определить среднюю плотность горныг пород в окрестностях профиля, что требуется при создания геологических карт, разведке полезных ископаемых и интерпретации наземных гравиметрических съемок.

Методика измерений и результаты. Измерения силы тяжести производятся в стационарном режиме, с интервалами глубины, которые разграничивают (сверху и снизу) слои горных пород, где неюбходимо определить величину плотности. После этого в два полученных значения силы тяжести и два значения глубины вносятся потравки. Откорректированные значения используются для расчета величины $\Delta g / \Delta z$, которая вставляется в уравнение для расчета плотности по величине силы тяжести.
Первоначапьно в скважине проводится разбивка каркасной и опорной сети. Далее выполняется рядовая съемка с шагом 1-3м, небольшими интервалами не более $50-70 \mathrm{M}$, для уменьшения погрешностей связанных с колебаниями температуры в скважине.

Так как скважинная гравиметрия является методом промысловой геофизики, интергретация результатов проводится в комплексе с данными ГИС (рис.2). В частности используется разность плотностей, которая определяется как разность гравиметрической плотности и плотности гамма-гамма каротажа, проинтегрированная на одном интервале глубины. Эта величина часто является индикатором присутствия подвижных углеводородов.

Имея данные о водонасыщенности и плотность, полученную по результатам гравиметрических измерений можно рассчитать пористость.

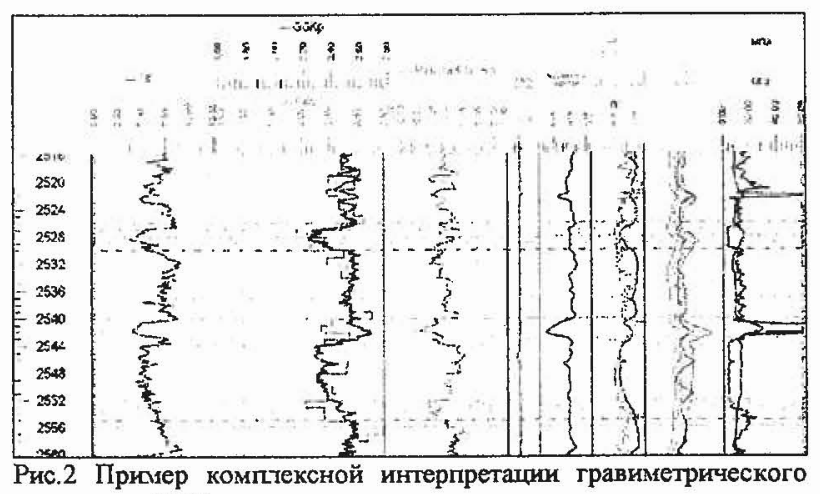
каротажа и ГИС

В качестве примера на рисунке 2 , в участке 2552-2556м выделен интервал, неявно заметный по данным ГИС, в отличие от интервала 2526-2530м, так как гравиметрический каротаж реагирует на удаленные структуры, недоступные другим методам, вследствие ограниченности их радиуса исследований.

Необходимо отметить некоторые несомненные преимущества гравиметрического каротажа по сравнению с другими методами ГИС: проведение замеров в обсаженной скважине, отсутствие влияния зоны проникновения, прямое влияние плотности, определение положения газо-водо-нефтяньг контактов на значительном удалении от скважины, отсутствие влияния магнитных и электрических полей.

Применение метода гравиметрического каротажа очень эффективно при поиске нефтегазовых залежей в новьх геологических райнах, так и при исследования уже известных месторождений для отределения продуктивности и прогнозной оценки нефтегазоотдачи залежей. В новых районах метод полезно использовать потому, что информация получаемая по результатам измерений имеет более широкий радиус исследований, чем стандартные методы ГИС. 